\title{
PENGARUH PEMBINAAN PENGAWAS DAN KEGIATAN MGMP TERHADAP KEMAMPUAN GURU PAI DALAM MELAKSANAKAN KURIKULUM 2013
}

\author{
Zumfiardi \\ Universitas Islam Negeri Imam Bonjol Padang \\ Email: zumfiardi@gmail.com
}

\begin{abstract}
This study aims to describe and analyze the influence of supervisors' training and PAI Teacher Subject deliberation activities on the ability of PAI Teachers to implement the 2013 Curriculum. This research was a field research type by using quantitative approach and associative methods. Respondents in this study were PAI Junior High School teachers in Padang. The findings of the study show that the guidance of supervisors to PAI teachers has a positive and significant effect on the ability of PAI teachers to implement the 2013 curriculum that is equal to 0.200 or 20.0\%. PAI Subject Teachers' Meeting (MGMP) has a positive and significant effect on the ability of PAI teachers to implement the 2013 curriculum of 0.208 or $20.8 \%$. Whereas supervisory guidance for PAI teachers and PAI Teacher Subject Meeting (MGMP) activities simultaneously had an influence on the ability of PAI teachers to implement the 2013 curriculum in SMPs in Padang City by 0.281 or 28.1\%. It is concluded that the guidance of school supervisors and the activities of the subject teacher deliberations had a positive influence on the ability of religious teachers to implement the 2013 curriculum. This implies that coaching needs to be empowered intensively.
\end{abstract}

Key Words: Supervisors' training, MGMP, PAI teacher

\section{PENDAHULUAN}

Kemampuan seorang guru sangat dibutuhkan dalam mengimplementasikan suatu kurikulum. Bagi guru yang mempunyai kemampuan yang baik apapun bentuk suatu kurikulum akan diupayakan penerapannya sebaik mungkin. Guru yang professional tidak akan merasa keberatan atau merasa berat tentang perubahan suatu kurikulum. Sebaliknya guru yang kemampuannya kurang akan merasakan perubahan kurikulum merupakan beban berat yang harus dipikulnya. Dalam dirinya sudah tertanam keinginan agar kurikulum tidak berubah-rubah. Bagi mereka cukuplah pengalaman-pengalaman mereka pada masa lalu yang ditransformasikan kepada peserta didiknya hari ini. Dengan demikian tentu ia tidak perlu repot-repot merancang pembelajaran yang akan dilaksanakan.

Stephen P. Robbins (1996), mengemukakan bahwa "kemampuan (ability) adalah kapasitas seorang individu untuk mengerjakan berbagai tugas dalam suatu pekerjaan". Hamzah B. Uno (2016) mendefenisikan "kemampuan adalah karakteristik yang menonjol pada seorang individu, yang berhubungan dengan kinerja efektif atau superior dalam suatu pekerjaan maupun situasi." J. Winardi (2007) mengemukakan bahwa "kemampuan (ability) merupakan merupakan sebuah sifat yang melekat pada manusia atau yang dipelajari, yang memungkinkan seseorang melaksanakan 
suatu tindakan atau pekerjaan mental atau fisikal". Senada dengan itu Keith Davis (2008) mengemukan bahwa "kemampuan merupakan perpaduan dari pengetahuan dan keteampilan. Hal ini ditunjukan dengan persamaan berikut: pengetahuan + keterampilan = kemampuan."

Kemampuan guru dalam menterjemahkan kurikulum ke dalam pembelajaran merupakan salah satu indikator mutu mengajar, sebab kurikulum merupakan pegangan guru dalam melaksanakan pembelajaran. Bagaimanapun luasnya kurikulum, ditambah dengan ketidak tersediaan fasilitas, jika ditangani oleh guru yang cakap pembelajaran menjadi bermakna bagi kehidupan masa depan peserta didiknya. Menurut Made Pidarta (2009), "supervisor itu adalah pembina guru, yang dapat saja diibaratkan sebagai gurunya guru" ". Sri Banun Muslim (2010) menyatakan bahwa "supervisi dan kurikulum merupakan dua bidang tugas yang berkaitan erat sebab supervisi dilaksanakan dalam rangka implementasi kurikulum. Fungsi supervisi dalam hal ini adalah membantu meningkatkan efektifitas pelaksanaan kurikulum".

Menurut Dadang Suhardan (2010) "Pembinaan merupakan kegiatan memperkenalkan cara-cara baru. Kegiatan ini dimaksudkan untuk menstimulasi, mengarahkan, memberi semangat agar guru-guru mau menerapkan cara-cara baru yang diperkenalkan sebagai hasil penemuan penelitian, termasuk dalam hal ini membantu guru-guru memecahkan masalah dan kesulitan dalam menggunakan cara-cara baru". Peran pengawas (supervisor) dalam memberikan pembinaan kepada guru dalam memahami tujuan sekolah, kurikulum dan pembelajaran akan berpengaruh kepada tingkat kemampuan seorang guru. Terkait dengan pengimplementasian kurikulum 2013 peran pengawas sangat di tuntut untuk membina guru dalam memahami tujuan dari kurikulum 2013 tersebut. Pengawas harus berusaha mengubah mindset guru agar dapat memahami bahwa perubahan kurikulum KTSP 2006 ke Kurikulum 2013 merupakan suatu langkah maju untuk meningkatkan mutu pendidikan di Indonesia. Dengan bimbingan yang maksimal dari pengawas diharapkan pengimplemen-tasian kurikulum 2013 dapat berjalan dengan baik dan sesuai dengan tujuan yang dirumuskan sebelumnya.

Pembinaan dan peningkatan kualitas kemampuan guru harus dilaksanakan secara sistematis dan kontiniu. Peningkatan kemampuan harus dibangun berdasarkan suatu keinginan guru untuk lebih baik dan meningkat. Selain pembinaan dari pengawas, menurut Amiruddin Siahaan (2010) "salah satu yang dapat meningkatkan kemampuan guru adalah melalui kegiatan Musyawarah Guru Mata Pelajaran (MGMP) atau juga Kelompok Kerja Guru (KKG)". Senada dengan hal itu menurut Suyanto (2013) "salah satu kegiatan yang selama ini dianggap efektif dalam meningkatkan kemampuan guru adalah melalui Musyawarah Guru Mata Pelajaran (MGMP)".

Beberapa penelitian terdahulu menemukan bahwa peran manajemen MGMP dalam meningkatkan profesionalitas guru PAI memiliki peran yang sangat penting sehingga keterlibatan semua guru PAI sangat diharapkan sesuai dengan tujuan pelaksanaan MGMP 
Hidayatullah Azizah (2012). Sri Hidayati (2012) juga menemukan bahwa kegiatan MGMP memiliki pengaruh positif terhadap Kompetensi Profesional guru, artinya semakin tinggi pengaruh kegiatan MGMP, maka akan semakin tinggi Kompetensi Profesional guru

\section{METODE PENELITIAN}

Jenis penelitian yang digunakan dalam penelitian ini adalah penelitian lapangan (field research) dengan pendekatan kuantitatif dan metode asosiatif. Populasi adalah guru PAI tingkat SMP di Kota Padang yang sudah melaksanakan kurikum 2013 berjumlah 35 orang yang ditetapkan dengan cara total sampling. Teknik pengumpulan data yang digunakan adalah angket (kuisioner) dan penilaian. Angket dan instrument penilaian yang digunakan telah dilakuan uji validitas konstruk (construct validity), uji validitas instrument dan uji reliabilitas instrument. Beberapa teknik analisis data yang digunakan adalah uji persyaratan analisis, uji normalitas, uji linieritas, uji asumsi klasik (uji multikolinieritas, uji heteroskedastisitas) dan uji hipotesis

\section{HASIL PENELITIAN DAN PEMBAHASAN}

Kemampuan Guru PAI Melaksanakan Kurikulum 2013

Kemampuan guru PAI melaksanakan Kurikulum 2013 di SMP se-Kota Padang merupakan variabel terikat atau dependent (Y). Data variable ini didapatkan dan diketahui setelah peneliti menyebarkan soal tes pengetahuan dan penilaian pelaksanaan proses belajar mengajar sesuai dengan Kurikulum 2013 kepada guru PAI yang menjadi sampel dalam penelitian ini.

Nilai kemampuan guru PAI melaksanakan Kurikulum 2013 di SMP seKota Padang bisa digambarkan dalam bentuk gambar histogram. Untuk lebih jelasnya, histogram kemampuan guru PAI melaksanakan Kurikulum 2013 di SMP seKota Padang dapat dilihat gambar histogram di bawah ini:

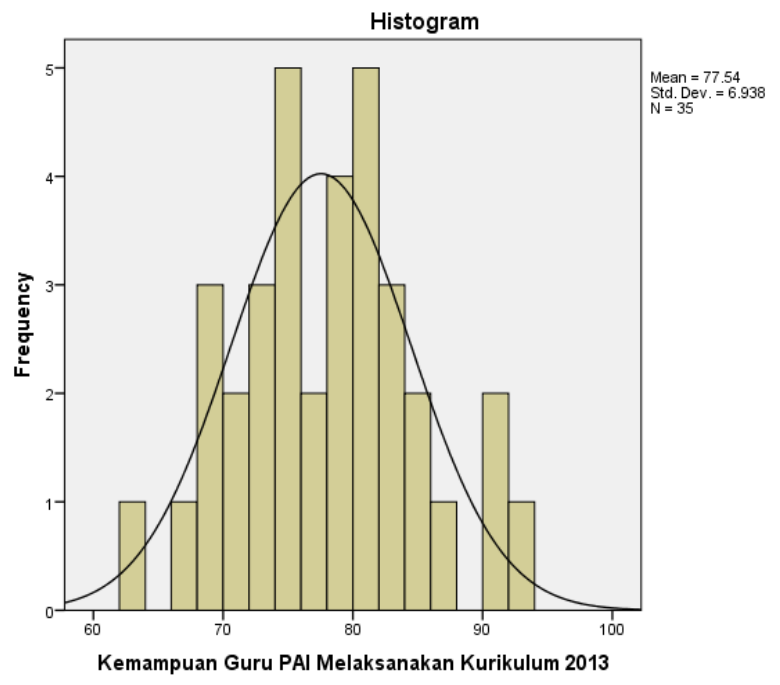

Gambar histogram di atas, menunjukkan bahwa batang histogram mempunyai kemiripan bentuk dengan kurva normal (berbentuk lonceng). Hal ini membuktikan bahwa distribusi tersebut sudah bisa dikatakan normal atau mendekati normal dengan rata-rata atau mean sebesar 77,54 nilai standar deviasi 6.938 dan $\mathrm{N}=35$.

Skor kemampuan guru PAI melaksanakan kurikulum 2013 di SMP seKota Padang sebagai berikut: 


\section{Kemampuan Guru PAI Melaksanakan Kurikulum 2013}

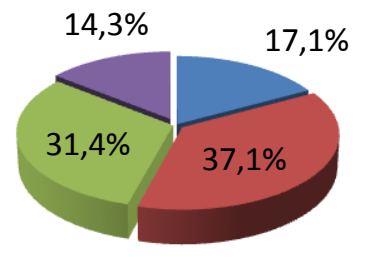

- Sangat Baik

Baik

Cukup Baik

Kurang Baik

Berdasarkan skor jawaban responden dapat diketahui bahwa sebanyak 6 responden $(17,1 \%)$ mempunyai kemampuan melaksanakan kurikulum 2013 pada kategori sangat baik, 13 responden (37,1 \%) berada dalam kategori baik, 11 responden (31,4 \%) dalam kategori cukup baik dan 5 responden (14,3\%) dalam kategori kurang baik. Dari hasil analisis statistik deskriptif diperoleh skor rata-rata (mean) kemampuan guru PAI melaksanakan kurikulum 2013 adalah 77,54 yang terletak pada interval 77 - 84 dengan kategori baik. Dengan demikian dapat dinyatakan bahwa kemampuan guru PAI melaksanakan kurikulum 2013 di SMP seKota Padang berada dalam kategori baik.

Secara umum hasil penelitian ini menggambarkan bahwa rata-rata kemampuan guru PAI melaksanakan kurikulum 2013 adalah baik. Namun perlu dicermati kembali bahwa guru merupakan ujung tombak dalam pelaksanaan kurikulum sehingga kemampuan seorang guru akan sangat berpengaruh terhadap keberhasilan kurikulum tersebut. Dari data penelitian ini peningkatan kemampuan guru PAI harus menjadi perhatian semua kalangan. Tingkat kemampuan dalam kategori "CUKUP BAIK" dan "KURANG BAIK" berada pada angka $45 \%$ artinya hampir setengah dari guru PAI belum mampu melaksanakan kurikulum 2013 dengan baik. Peningkatan kemampuan guru PAI harus menjadi prioritas bagi pihak pengambil keputusan.

Menurut E. Mulyasa (2015) “Tanpa guru profesional perubahan kurikulum tidak akan memberikan sumbangan yang berarti terhadap kualitas pembelajaran dan mutu lulusan pada umumnya. Oleh karena itu, untuk menyukseskan implementasi Kurikulum 2013, perlu dipersiapkan guru profesional yang mampu merencanakan, melaksanakan, melakukan monitoring dan evaluasi, serta memberikan jaminan mutu dan mempertanggungjawabkan pembelajaran sesuai dengan karakteristik dan perkembangan peserta didik, perkembangan zaman, kebutuhan pembangunan, serta perkembangan ilmu pengetahuan teknologi dan seni."

Berdasarkan hasil penelitian dan pendapat ahli di atas maka titik tekan peningkatan kemapuan guru PAI adalah dalam hal merencanakan pembelajaran, melaksanakan pembelajaran dan menilai pembelajaran. Ketiga point ini harus menjadi perhatian serius bagi guru PAI, ketika guru PAI sudah bisa merencanakan apa yang akan dilaksanakan serta melaksanakan apa yang direncanakan maka disitulah salah satu indicator kesuksesan pelaksanaan kurikulum 2013.

\section{Pembinaan Pengawas Kepada Guru PAI}

Pembinaan pengawas kepada guru 
PAI merupakan salah satu variabel bebas atau variabel yang mempengaruhi (variabel independent). Untuk mendapatkan nilai pembinaan pengawas kepada guru PAI, penulis menyebar angket tentang pembinaan pengawas kepada guru PAI dengan jumlah item pernyataan sebanyak 36 item dengan empat alternative jawaban yaitu selalu (4), sering (3), kadang-kadang (2) dan tidak pernah (1). Angket disebarkan kepada 35 orang guru PAI yang menjadi sampel dalam penelitian ini.

Nilai pembinaan pengawas kepada guru PAI di SMP se-Kota Padang bisa digambarkan dalam bentuk gambar histogram. Untuk lebih jelasnya, histogram pembinaan pengawas kepada guru PAI di SMP se-Kota Padang dapat dilihat gambar histogram di bawah ini:

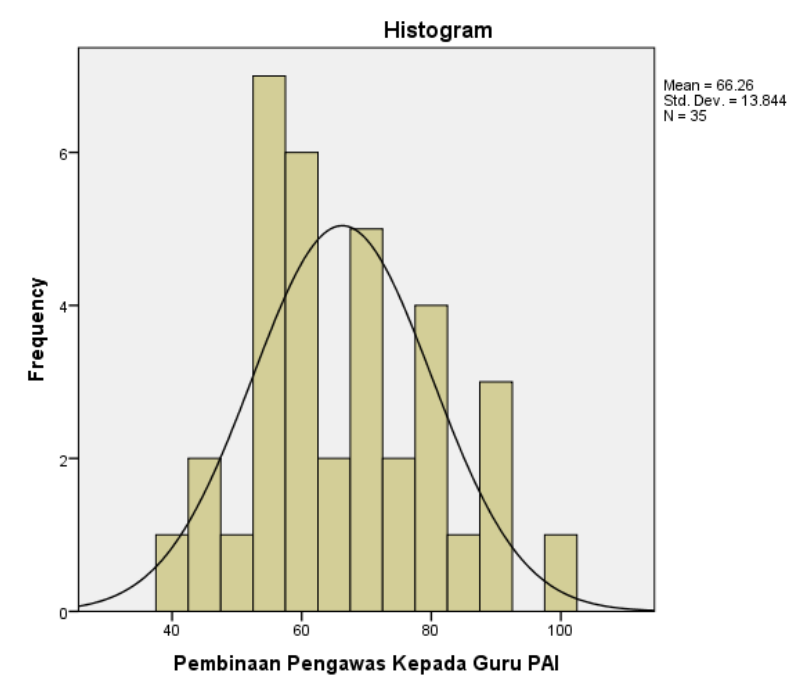

Gambar histogram di atas, menunjukkan bahwa batang histogram mempunyai kemiripan bentuk dengan kurva normal (berbentuk lonceng). Hal ini membuktikan bahwa distribusi tersebut sudah bisa dikatakan normal atau mendekati normal dengan rata-rata atau mean sebesar 66,26 nilai standar deviasi
13,844 dan jumlah data adalah 35 .

Sedangkan skor pembinaan pengawas kepada guru PAI di SMP seKota Padang sebagai berikut:

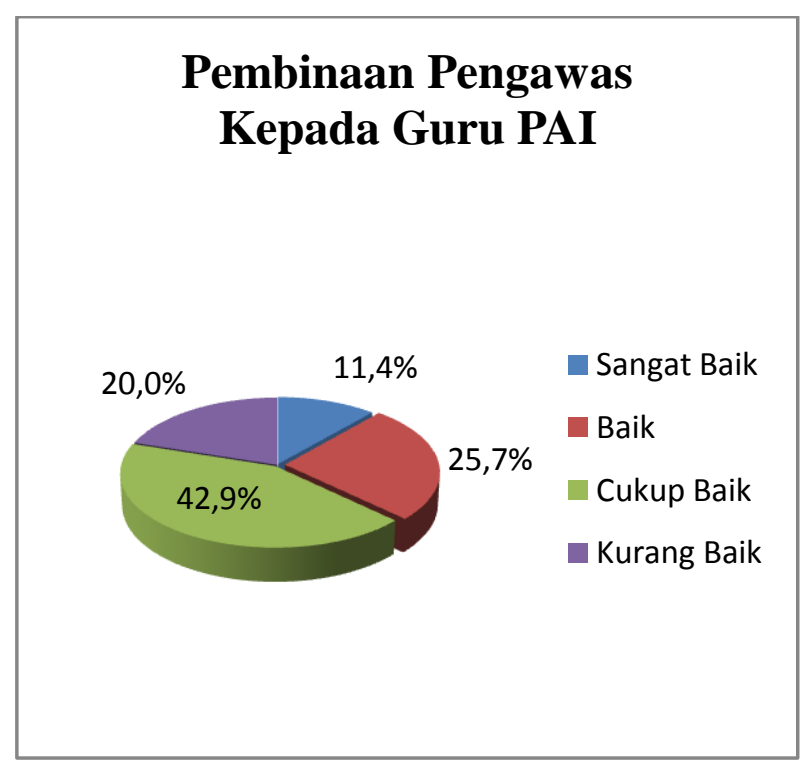

Berdasarkan skor jawaban responden dapat diketahui bahwa sebanyak 4 responden $(11,4 \%)$ memberikan skor pembinaan pengawas kepada guru PAI di SMP se-Kota Padang pada kategori sangat baik, 9 responden (25,7 \%) memberikan skor dalam kategori baik, 15 responden $(42,9 \%)$ dalam kategori cukup baik dan 7 responden (20.0\%) dalam kategori kurang baik. Dari hasil analisis statistik deskriptif diperoleh skor rata-rata (mean) pembinaan pengawas adalah 66,25 yang terletak pada interval 55 - 69 dengan kategori cukup baik. Dengan demikian dapat dinyatakan bahwa pembinaan pengawas kepada guru PAI berada dalam kategori cukup baik.

Data penelitian ini menggambarkan bahwa pembinaan pengawas kepada guru PAI baru berada pada kategori "CUKUP BAIK". Ini artinya guru PAI belum medapatkan pembinaan yang maksimal 
dari pengawas PAI. Untuk saat ini guru PAI masih belum mendapatkan pembinaan yang maksimal dari pengawas. Dilihat dari data pengawas PAI kota Padang, hal ini harus dapat dimaklumi. Data kepengawasan menggambarkan betapa kurangnya jumlah pengawas PAI untuk kota Padang. Kondisi saat ini pengawas PAI berjumlah 4 orang dengan jumlah sekolah yang harus dibina lebih dari 170 SMP/SMA/SMK negeri/swasta dengan perkiraan jumlah guru PAI lebih dari 500 orang. Menyikapi data penelitian dan kondisi nyata dilapangan maka penambahan pengawas PAI menjadi mutlak harus dilakukan.

Pembinaan pengawas menjadi salah satu kunci sukses keberhasilan pelaksanaan kurikulum 2013. Menurut Eugene J. Benge (1994) pembinaan melampaui pelatihan, pembinaan menghendaki perubahan dalam sikap, kebiasaan kerja, dan sifat-sifat pribadi, serta perubahan dalam pembelajaran, pengambilan keputusan dan pemecahan masalah. Terkait dengan pengimplementasian kurikulum 2013 peran pengawas sangat di tuntut untuk membina guru dalam memahami tujuan dari kurikulum 2013 tersebut. Pengawas harus berusaha mengubah mindset guru agar dapat memahami bahwa perubahan kurikulum KTSP 2006 ke Kurikulum 2013 merupakan suatu langkah maju untuk meningkatkan mutu pendidikan di Indonesia. Dengan bimbingan yang maksimal dari pengawas diharapkan pengimplementasian kurikulum 2013 dapat berjalan dengan baik dan sesuai dengan tujuan yang dirumuskan sebelumnya.
Kegiatan Musyawarah Guru Mata Pelajaran (MGMP) PAI

Kegiatan Musyawarah Guru Mata Pelajaran (MGMP) PAI merupakan salah satu variabel bebas atau variabel yang mempengaruhi (variabel independent). Untuk mendapatkan nilai kegiatan Musyawarah Guru Mata Pelajaran (MGMP) PAI, disenyebar angket terkait dengan kegiatan Musyawarah Guru Mata Pelajaran (MGMP) PAI dengan jumlah item pernyataan sebanyak 41 item dengan empat alternative jawaban yaitu selalu (4), sering (3), kadang-kadang (2) dan tidak pernah (1). Angket penelitian disebarkan kepada 35 orang guru PAI yang menjadi sampel dalam penelitian ini.

Nilai kegiatan Musyawarah Guru Mata Pelajaran (MGMP) PAI SMP se-Kota Padang bisa digambarkan dalam bentuk gambar histogram. Untuk lebih jelasnya, histogram kegiatan Musyawarah Guru Mata Pelajaran (MGMP) PAI SMP se-Kota Padang dapat dilihat gambar histogram di bawah ini:

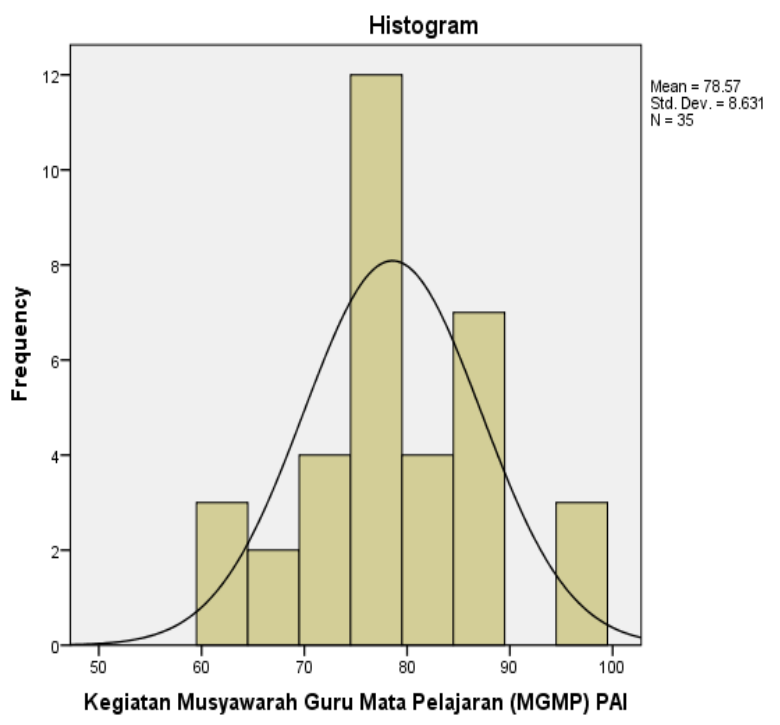

Gambar histogram di atas, menunjukkan bahwa batang histogram 
mempunyai kemiripan bentuk dengan kurva normal (berbentuk lonceng). Hal ini membuktikan bahwa distribusi tersebut sudah bisa dikatakan normal atau mendekati normal dengan rata-rata atau mean sebesar 78,57 nilai standar deviasi 8,631 dan jumlah data adalah 35 .

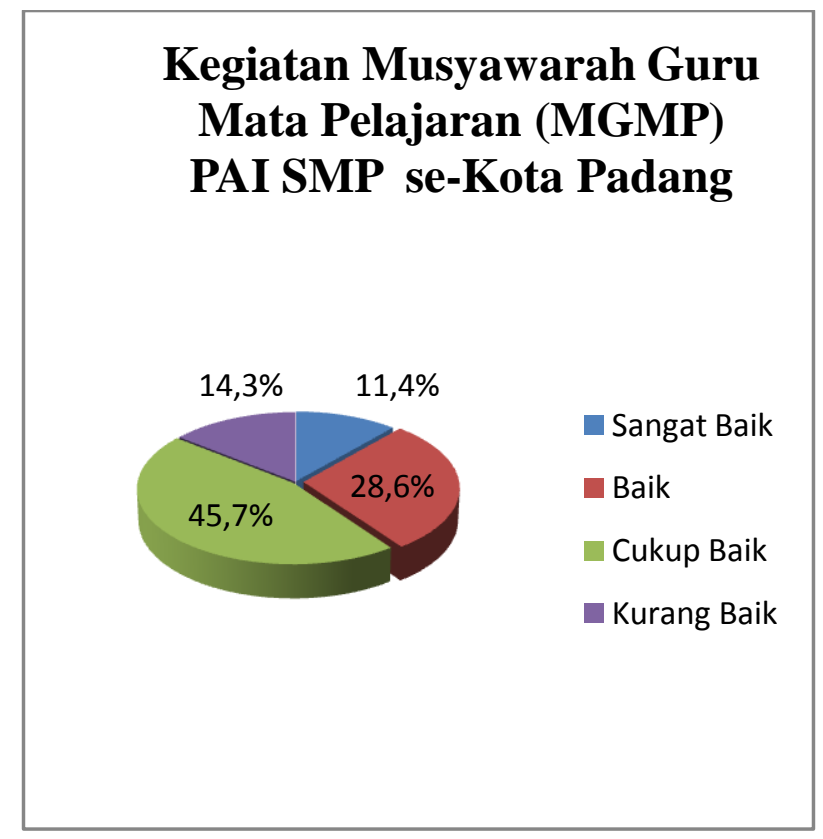

\begin{tabular}{llrr}
\multicolumn{2}{c}{ Berdasarkan } & skor & jawaban \\
responden & dapat & diketahui & bahwa \\
sebanyak & 4 & responden & $(11,4 \%)$
\end{tabular} memberikan skor kegiatan Musyawarah Guru Mata Pelajaran (MGMP) PAI SMP se-Kota Padang pada kategori sangat baik, 10 responden $(28,6 \%)$ memberikan skor dalam kategori baik, 16 responden $(45,7$ \%) dalam kategori cukup baik dan 5 responden (14,3\%) dalam kategori kurang baik. Dari hasil analisis statistik deskriptif diperoleh skor rata-rata (mean) kegiatan Musyawarah Guru Mata Pelajaran (MGMP) PAI SMP se-Kota Padang adalah 78,57 yang terletak pada interval 71 - 79 dengan kategori cukup baik. Dengan demikian dapat dinyatakan bahwa kegiatan Musyawarah Guru Mata Pelajaran (MGMP) PAI SMP se-Kota
Padang berada dalam kategori cukup baik.

Keberadaan MGMP memiliki manfaat bagi guru PAI. Dengan adanya MGMP para guru PAI akan saling berbagi informasi terkait dengan persoalanpersoalan yang mereka hadapi di sekolah masing-masing. Para guru secara bersama-sama merancang program kerja, menanalisa metode-meode pembelajaran yang tepat untuk diterapakan di sekolah masing-masing agar tujuan dari pembelajaran PAI dapat tercapai. Dengan adanya komunikasi yang intens antara guru PAI ini maka tentu tingkat kemampuan guru terutama sekali dalam menerapkan kurikulum 2013 akan meningkat dan apa yang diharapakan dari penerapan kurikulum 2013 ini dapat tercapai dengan baik.

Program kegiatan MGMP akan memberikan dampak yang positif bagi para guru jika program yang dilaksanakan selalu dievaluasi dan dilakukan perbaikan untuk kebaikan bersama. Jika program MGMP hanya bersifat serimonial dan formalitas saja tentu tidak akan memberikan dampak yang baik bagi para guru. Kerjasama yang baik antara pengurus MGMP dan para guru sebagai anggota dalam menyusun program kegiatan akan membawa dampak positif bagi semua anggota dan motivasi untuk mengikuti kegiatan tersebut akan lebih baik. Selain program yang terrsusun dengan baik MGMP juga harus mendapat dukungan dari sekolah, Dinas Pendidikan, Kementrian Agama Kota dan pengawas PAI baik secara moril maupun materil.

Berdasarkan data hasil penelitian didapat gambaran bahwa kondisi saat ini guru PAI baru merasakan manfaat MGMP 
baru berada pada kategori "CUKUP BAIK". Hal ini harus menjadi perhatian bagi pengurus MGMP bagaimana untuk selanjutnya kegiatan MGMP betul-betul menyetuh level kebutuhan nyata guru. Kegiatan MGMP idealnya harus bias menjawab persoalan-persoalan yang dihadapi di sekolah.

Perubahan kurikulum pada dasarnya merupakan sebuah langkah untuk memajukan pendidikan. Suatu kurikulum yang baik tentu harus selalu dievaluasi tingkat keberhasilannya dalam mencapai tujuan yang telah ditetapkan. Kurikulum 2013 merupakan pengembangan dari KTSP 2006 untuk merespons berbagai tantangan-tantangan yang terjadi di dunia pendidikan dan merespon persaingan-persaingan global. Titik tekan Kurikulum 2013 adalah penyempurnaan pola pikir, penguatan tata kelola kurikulum, pendalaman dan perluasan materi, penguatan proses pembelajaran dan penyesuaian beban belajar agar dapat menjamin kesesuaian antara apa yang diinginkan dan apa yang dihasilkan.

Kemampuan seorang guru memiliki peran yang sangat penting dalam implementasi kurikulum, terutama saat ini yang menggunakan kurikulum 2013. Guru harus mampu menterjemahkan serta menjabarkan nilai-nilai yang terdapat dalam kurikulum 2013, kemudian mentransformasikan nilai-nilai tersebut kepada peserta didik melalui proses pembelajaran di dalam maupun di luar kelas. Guru harus menyadari bahwa dalam melaksanakan tugas harus selalu menyesuaikan diri dan kemampuan dengan perkembangan zaman, oleh karena itu guru dituntut untuk selalu meningkatkan pengetahuan dan keterampilan sesuai tuntutan profesinya.

Berdasarkan hasil analis data penelitian yang sudah dilakukan diketahui bahwa pembinaan pengawas memberikan kontribusi yang positif sebesar 20\% terhadap kemampuan guru melaksankan kurikulum 2013 dan 80\% lagi dikontribusi oleh varibel lain yang tidak termasuk dalam penelitian ini. Hasil regresi liner antar pembinaan pengawas terhadap kemampuan guru PAI melaksanakan kurikulum 2013 menunjukkan bahwa jika nilai variabel bebas (X1) atau pembinaan pengawas naik satu satuan maka variabel terikat $(\mathrm{Y})$ atau kemampuan guru PAI melaksanakan kurikulum 2013 dapat diprediksi akan meningkat sebesar 0,224 atau 22,4\% pada konstanta 62,687. Dengan demikian dapat disimpulkan bahwa semakin baik dan meningkat pembinaan pengawas kepada guru PAI maka kemampuan guru PAI melaksanakan kurikulum 2013 akan semakin baik dan meningkat juga.

Hal ini senada dengan pendapat Dadang Suhardan (2010) “Pembinaan merupakan kegiatan memperkenalkan cara-cara baru. Kegiatan ini dimaksudkan untuk menstimulasi, mengarahkan, memberi semangat agar guru-guru mau menerapkan cara-cara baru yang diperkenalkan sebagai hasil penemuan penelitian, termasuk dalam hal ini membantu guru-guru memecahkan masalah dan kesulitan dalam menggunakan cara-cara baru" (Dadang Suhardan, 2010). Peran pengawas (supervisor) dalam memberikan pembinaan kepada guru dalam memahami tujuan sekolah, kurikulum dan pembelajaran akan berpengaruh kepada tingkat kemampuan seorang guru. Pengawas harus berusaha mengubah 
mindset guru agar dapat memahami bahwa perubahan kurikulum KTSP 2006 ke Kurikulum 2013 merupakan suatu langkah maju untuk meningkatkan mutu pendidikan di Indonesia. Dengan bimbingan yang maksimal dari pengawas diharapkan pengimplementasian kurikulum 2013 dapat berjalan dengan baik dan sesuai dengan tujuan yang dirumuskan sebelumnya.

Beberapa hal yang harus dilakukan oleh pengawas untuk membantu guru meningkatkan kinerjanya, yaitu: Membantu guru membuat perencanaan pembelajaran; Membantu guru untuk menyajikan pembelajaran; Membantu guru untuk mengevaluasi pembelajaran; Membantu guru untuk mengelola kelas; Membantu guru dalam mengembangkan kurikulum; Membantu guru dalam mengevaluasi kurikulum; Membantu guru melalui program pelatihan; Membantu guru untuk melakukan kerja sama; Membantu guru untuk mengevaluasi diri sendiri (Syaiful Sagala, 2013).

Berdasarkan hasil penelitian dan pendapat pakar tersebut maka pengawas PAI sudah seharunya selalu meningkatkan kemampuan pribadinya sehingga akan bisa memberikan pembinaan yang bermutu kepada guru PAI. Peningkatan kemampuan pengawas ini sangat diperlukan baik sebagai pendidikan formal atau non formal. Berdasarkan Keputusan MENPAN Nomor 118/1996 pada Bab X pasal 22 dan 23 telah ditetapkan bahwa pengawas mata pelajaran/rumpun mata pelajaran di Sekolah Lanjutan Tingkat Pertama (SLTP)/Madrasah Tsanawiyah (MTs) atau Sekolah Menengah Umum dan Kejuruan (SMU/SMK) atau Madrasah Aliyah (MA) pendidikan serendah-rendahnya Magister (S-2) atau yang sederajat; dan berkedudukan serendah-rendahnya guru dewasa.

Hasil penelitan juga mengungkap bahwa kegiatan MGMP PAI memberikan kontribusi yang positif sebesar 20,8\% terhadap kemampuan guru melaksankan kurikulum 2013 dan 79,2\% lagi dikontribusi oleh varibel lain yang tidak termasuk dalam penelitian ini. Hasil regresi liner antar kegiatan MGMP PAI terhadap kemampuan guru PAI melaksanakan kurikulum 2013 menunjukkan bahwa jika nilai variabel bebas (X2) atau kegiatan MGMP PAI naik satu satuan maka variabel terikat $(Y)$ atau kemampuan guru PAI melaksanakan kurikulum 2013 dapat diprediksi akan meningkat sebesar 0,366 atau 36,6\% pada konstanta 48,748. Dengan demikian dapat disimpulkan bahwa semakin baik dan meningkat kegiatan MGMP PAI maka kemampuan guru PAI melaksanakan kurikulum 2013 akan semakin baik dan meningkat juga.

Manusia sebagai makhluk sosial senantiasa membutuhkan orang lain dalam menjalani kehidupannya. Sifat saling ketergantungan ini mengatarkan manusia untuk membentuk organisasi mulai dari yang klasik hingga yang moderen. MGMP (Musyawarah Guru Mata Pelajaran) adalah forum/organisasi kegiatan profesional guru mata pelajaran pada SMP/MTs, SMPLB/MTsLB, SMA/MA, SMK/MAK, SMALB/MALB yang berada pada satu wilayah/kabupaten/kota/ kecamatan/ sanggar/gugus sekolah. Keikutsertaan guru dalam kegiatan MGMP membuka peluang bagi mereka untuk memecahkan persoalan yang dihadapi di sekolah secara 
bersama. Guru bisa berdiskusi dengan teman sejawat berkaitan dengan masalahmasalah perkembangan dunia pendidikan agar mereka tidak ketinggalan informasi terbaru.

Program kegiatan MGMP akan memberikan dampak yang positif bagi para guru jika program yang dilaksanakan selalu dievaluasi dan dilakukan perbaikan untuk kebaikan bersama. Jika program MGMP hanya bersifat serimonial dan formalitas saja tentu tidak memberikan dampak yang baik bagi para guru. Kerjasama yang baik antara pengurus MGMP dan para guru sebagai anggota dalam menyusun program kegiatan membawa dampak positif bagi semua anggota dan motivasi untuk mengikuti kegiatan tersebut akan lebih baik. Selain program yang tersusun dengan baik MGMP juga harus mendapat dukungan dari sekolah, Dinas Pendidikan, Kementrian Agama Kota dan pengawas PAI baik secara moril maupun materil.

Hasil penelitan juga mengungkap bahwa pembinaan pengawas dan kegiatan MGMP PAI secara bersamaan memberikan kontribusi yang positif sebesar 28,1\% terhadap kemampuan guru melaksanakan kurikulum 2013 dan 71,9\% lagi dikontribusi oleh varibel lain yang tidak termasuk dalam penelitian ini. Hasil regresi liner antar pembinaan pengawas dan kegiatan MGMP PAI secara bersamaan terhadap kemampuan guru PAI melaksanakan kurikulum 2013 menunjukkan bahwa jika nilai variabel bebas (X1) atau pembinaan pengawas naik satu satuan dan variabel bebas (X2) atau kegiatan MGMP PAI tetap maka variabel terikat (Y) atau kemampuan guru PAI melaksanakan kurikulum 2013 dapat diprediksi akan meningkat sebesar 0,152 atau $15,2 \%$ pada konstanta 47.294. Demikian juga jika nilai variabel bebas (X2) atau kegiatan MGMP PAI naik satu satuan dan variabel bebas (X1) atau pembinaan pengawas tetap maka variabel terikat (Y) atau kemampuan guru PAI melaksanakan kurikulum 2013 dapat diprediksi akan meningkat sebesar 0,257 atau 25,7\% pada konstanta 47.294. Dengan demikian dapat disimpulkan bahwa semakin baik dan meningkat pembinaan pengawas dan kegiatan MGMP PAI maka kemampuan guru PAI melaksanakan kurikulum 2013 semakin baik dan meningkat juga.

Musyawarah Guru Mata Pelajaran (MGMP) merupakan forum pertemuan sesama guru mata pelajaran. Forum ini tidak hanya dihadiri oleh guru saja tetapi pengawas juga ikut hadir dalam forum ini dalam rangka memenuhi tugas dan kewajibannya. Kehadiran pengawas dalam forum MGMP tentunya bertujuan untuk memberikan pembinaan kepada guru bidang studi. Sejalannya pembinaan yang diberikan pengawas dan kegiatan MGMP berdampak positif bagi peningkatan kemampuan guru PAI secara umum. Keterbatasan jumlah pengawas untuk memberikan pembinaan kepada guru PAI dapat teratasi dengan adanya kegiatan MGMP. Kehadiran pengawas dalam kegiatan MGMP adalah untuk memberikan pembinaan secara berkelompok kepada guru binaannya. Guru yang hadir dan mengikuti kegiatan MGMP secara rutin tentu mendapatkan pembinaan dari pengawas.

Berdasarkan hasil penelitian dan pembahasan ini dapat diketahuai bahwa kemampuan guru PAI melaksanakan kurikulum 2013 di SMP se-Kota Padang 
berada pada kategori baik sedangkan pembinaan pengawas kepada guru PAI berada pada kategori cukup baik dan variabel kegiatan Musyawarah Guru Mata Pelajaran (MGMP) PAI berada pada kategori cukup baik. Temuan ini membawa implikasi terhadap pentingnya meningkatkan pembinaan pengawas kepada guru PAI dan juga meningkatkan kegiatan Musyawarah Guru Mata Pelajaran (MGMP) PAI agar kemampuan guru PAI melaksanakan kurikulum 2013 di SMP se-Kota Padang meningkat.

\section{PENUTUP}

Hasil uji hipotesis membuktikan bahwa pembinaan pengawas kepada guru PAI dan kegiatan Musyawarah Guru Mata Pelajaran (MGMP) PAI memberikan pengaruh yang positif dan signifikan terhadap kemampuan guru PAI melaksanakan kurikulum 2013 di SMP seKota Padang baik secara sendiri-sendiri maupun secara bersama-sama. Hal ini berarti untuk meningkatkan kemampuan guru PAI melaksanakan kurikulum 2013 di SMP se-Kota Padang dapat dilakukan dengan meningkatkan pembinaan pengawas kepada guru PAI dan kegiatan Musyawarah Guru Mata Pelajaran (MGMP) PAI.

Klasifikasi rata-rata variabel kemampuan guru PAI melaksanakan kurikulum 2013 di SMP se-Kota Padang berada pada kategori baik sedangkan variabel pembinaan pengawas kepada guru PAI berada pada kategori cukup baik dan variabel kegiatan Musyawarah Guru Mata Pelajaran (MGMP) PAI berada pada kategori cukup baik. Temuan ini membawa implikasi terhadap pentingnya meningkatkan pembinaan pengawas kepada guru PAI dan juga meningkatkan kegiatan Musyawarah Guru Mata Pelajaran (MGMP) PAI agar kemampuan guru PAI melaksanakan kurikulum 2013 di SMP se-Kota Padang meningkat.

Sehubungan dengan itu, saran yang dapat diberikan terkait dengan hasis penelitian ini adalah:

Kepada guru-guru PAI SMP se-Kota Padang untuk dapat terus berupaya meningkatkan kemampuan dalam melaksanakan proses belajar mengajar dan meningkatkan kemampuan melaksanakan kurikulum 2013. Saling bekerjasama dan saling memotivasi sesama guru PAI dalam meningkatkan kemampuan melaksanakan proses belajar mengajar agar mutu Pendidikan Agama Islam meningkat dan menjadi lebih baik serta sesuai dengan harapan dalam mencapai tujuan pendidikan nasional.

Kepada pengurus Musyawarah Guru Mata Pelajaran (MGMP) PAI SMP Kota Padang agar terus berupaya untuk meningkatkan kualitas dan kuantitas kegiatan MGMP. Kegiatan MGMP sudah dirasakan manfaatnya oleh para anggota atau guru PAI, namun tentu kulitas materi, kualitas nara sumber sangat perlu untuk dievaluasi dan ditingkatkan lagi. Peningkatan kualitas kegiatan MGMP berdampak positif terhadap kemampuan guru melaksanakan proses belajar mengajar. Keterbatasan kesempatan bagi guru PAI dalam mengikuti pelatihan kurikulum 2013 baik tingkat daerah maupun tingkat nasional, tentu bisa teratasi dengan kegiatan MGMP yang berhubungan dengan kurikulum 2013.

Kepada pengawas PAI Kota Padang agar terus berupaya memberikan pembinaan secara intensif kepada guru PAI. Pembinaan motovasi dan bimbingan dari pengawas PAI sangat dibutuhkan 
untuk meningkatkan kemampuan mengajar guru PAI. Dengan adanya pembinaan pengawas PAI secara berkesinambungan tentu membangun kerjasama yang baik antara pengawas dan guru PAI. Kerjasama yang baik antara pengawas dan guru tentu dapat meningkatkan mutu Pendidikan Agama Islam. Pembinaan pengawas mengenai regulasi tentang kurikulum 2013 sangat diharapkan oleh guru PAI dalam rangka meningkatkan kemampuannya melaksanakan kurikulum 2013.

\section{REFERENSI}

Arikunto, Suharsimi, Prosedur Penelitian: Suatu Pendekatan Praktik, Jakarta: Rineka Cipta, 2002

Bafadal,Ibrahim, Peningkatan Profesionalisme Guru Sekolah Dasar, Jakarta: PT. Bumi Aksara, 2009

Bungin,Burhan, Metodologi Penelitian Kuantitaif, Jakarta: Kencana, 2014

Danim,Sudarwan, Profesionalisasi dan Etika Profesi Guru, Bandung: Alvabeta, 2010

Davis, Keith dan Jhon W. Newstrom, Perilaku dalam Organisasi, Jilid 2; Alih Bahasa: Agus Dharman; Judul Asli: Human Behavior at Work: Organization Behavior, Seventh Edition, Jakarta: Penerbit Erlangga, 2008

Depertemen Pendidikan Nasional, Standar Pengembanga Kelompok Kerja Guru (KKG) dan Musyawarah Guru Mata Pelajaran (MGMP), Jakarta: 2008
E. Mulyasa, Implementasi Kurikulum Tingkat Satuan Pendidikan; Kemandirian Guru dan Kepala Sekolah, Jakarta: Bumi Aksara, 2010

Pengembangan dan Implementasi Kurikulum 2013, Bandung: PT. Remaja Rosda karya, 2013

Guru dalam Implementasi Kurikulum 2013, Bandung: Remaja Rosda Karya, 2015

Imran, Ali, Supervisi Pembelajaran Tingkat Satuan Pendidikan, Jakarta: Bumi Aksara, 2012

Jack.R, Fraenkel dkk, How to Design and Evaluate Reseach in Education, second edision, New York: Mc.Graw-Hill.Inc, 1993

Kunandar, Guru Profesional, Implementasi Kurikulum Tingkat Satuan Pendidikan dan Sukses dalam Sertifikasi Guru, Jakarta: PT. Raja Grafindo Persada, 2011

Muijs, Daniel, Doing Quantitative Research in Educational, London: Sage Puplications, 2004

Muslim, Sri Banun, Supervisi Pendidikan Meningkatkan Kualitas Profesional Guru, Bandung: Alfabeta, 2010

Nurdin,Syafruddin, Kurikulum dan Pembelajaran, Jakarta: Rajawali Pers, 2016

Pidarta,Made, Supervisi Pendidikan Kontekstual, Jakarta : Rineka Cipta, 2009

Riadi, Edi, Statistika Penelitian (Analisis Manual dan IBM SPSS), Yogyakarta: Andi Offset, 2016 
Robbins, Stephen P.,Perilaku Organisasi; Konsep, Kontroversi, Aplikasi, Alih Bahasa: Hadyana Pujaatmaka; Judul Asli: Organizational Behavior, Jakarta: Prenhallindo, 1996

Rusman, Pembelajaran Tematik Terpadu: Teori, Praktik dan Penilaian, Jakarta: Rajawali Pers, 2015

Sagala,Syaiful, Supervisi Pembelajaran, dalam Profesi Pendidikan, Bandung: Alvabeta, 2012

Siahaan,Amiruddin dkk, Manajemen Pengawas Pendidikan, Jakarta: Quantum Teaching Ciputat Press Group, 2006
Suhardan, Dadang, Supervisi Profesional (Layanan dalam Meningkatkan Mutu Pengajaran di Era Otonomi Daerah), Bandung: Alfabeta, 2010

Suyanto, Menjadi Guru Profesional; Strategi Meningkatkan Kualifikasi Dan Kualitas Guru di Era Global, Jakarta: Erlangga Group, 2013

Uno, Hamzah B., Tugas Guru dalam Pembelajaran Aspek yang Mempengaruhi, Jakarta: Bumi Aksara, 2016 
92 || Turast: Jurnal Penelitian dan Pengabdian Vol. 6, No. 1, Januari-Juli 2018 
